\title{
Two sides of the same coin: increasing material extraction rates and social environmental conflicts in Mexico
}

\author{
Darcy Tetreault ${ }^{1}$ (1)
}

Received: 14 October 2020 / Accepted: 27 November 2021 / Published online: 1 January 2022

(C) The Author(s) 2021

\begin{abstract}
This article seeks to explain the multiplication of social environmental conflicts in Mexico as a consequence of expanding and intensifying extractive activities. It examines how the Mexican state has provided private and foreign capital greater access to the country's natural resources in the transition from state-led import-substituting industrialization to export-oriented market-led development. This, it argues, has led to accelerating material extraction rates in the context of rising global demand for primary commodities; while the negative environmental and social impacts have in turn led to a growing number of conflicts involving the inhabitants of directly affected rural communities, who organize to resist. Based on standardized procedures for material flow analysis, it presents the results of an investigation into the domestic extraction rates of minerals, metal ores, biomass, and fossil fuels from Mexico, between 1990 and 2018. It finds that domestic extraction rates increased significantly during this period, with the exception of fossil fuels, which peaked in 2006, declining thereafter due to the exhaustion of the country's most important oil reserves. The evolution of domestic extraction rates is juxtaposed with the emergence of related social environmental conflicts by drawing on multiple databases of conflicts around extractive activities in Mexico.
\end{abstract}

Keywords Social metabolism $\cdot$ Extractivism $\cdot$ Environmental conflict $\cdot$ Mexico

\section{Introduction}

Hundreds of social environmental conflicts (SECs) have emerged in Mexico since the 1990s. Most of these revolve around extractive activities in mining, petroleum, biomass extraction, and dam building (Toledo et al., 2015). Typically, these conflicts involve directly impacted rural communities whose members organize and form alliances among themselves and with solidarity organizations to resist extractive projects that are promoted by private companies and the state. The latter make appeals to notions of progress, economic growth, and modernization, while the former struggle to defend territories, healthy

Darcy Tetreault

darcytetreault@yahoo.com

1 Universidad Autónoma de Zacatecas, Unidad Académica en Estudios del Desarrollo,

Zacatecas, Zacatecas, Mexico 
living environments, biocultural diversity, sacred sites, and traditional livelihoods in smallscale farming (Tetreault et al., 2018).

This article seeks to help explain the multiplication of SECs in Mexico during the neoliberal era by analyzing the underlying material and biophysical conditions associated with the "extractivist drive" (Arsel et al., 2016). While Mexico's economy has not been "reprimarized" to the same extent as those of South America (Cypher, 2010), the rates of extracting materials from the country have nevertheless increased dramatically over the past three decades. The first objective of this paper is to demonstrate this, using procedures that correspond to standardized methods for material flow analysis (MFA) — as developed by EUROSTAT $(2001,2018)$ and made applicable globally by Krausmann et al. (2015) in order to provide an economy-wide analysis of the country's domestic material extraction rates. The main argument is two-fold: first, that neoliberal structural adjustments, by giving capital greater access to Mexico's natural resources, have facilitated an increase in domestic extraction rates in the context of growing global demand; and second, that this increase in what can be conceptualized as a key feature of the "social metabolism" of the Mexican economy is driving an increase in the number of SECs, although not in a mechanical fashion since objective conditions of environmental degradation and injustice do not automatically translate into organized resistance.

The argument is developed as follows. Section one after this introduction frames the analysis of material flow rates around the concept of social metabolism and summarily examines patterns of material flow on the global and regional levels. Section two briefly reviews the transition in Mexico from state-led import-substituting industrialization (ISI) during the post-World War II period to market-led export-oriented development from the 1980s on, pointing to how this transition has provided private and foreign capital greater access to the country's natural resources. Section three discusses the nature of SECs and reviews the literature on the relation between increasing material flow rates and the multiplication of SECs. Section four outlines the method used in this investigation to calculate domestic extraction rates in Mexico for minerals, metal-ores, fossil fuels, and biomass. It also presents the databases used to analyze general tendencies in the emergence of SECs in Mexico, indicating the methods used to identify cases and systematize relevant information. Section five presents findings on the rates of extracting materials from Mexico between 1990 and 2018; it juxtaposes these to related SECs, and it seeks to explain observed tendencies in relation to global market conditions, state policies, and struggles of resistance. The last section briefly sums up the conclusions that can be drawn from this analysis.

\section{Social metabolism and material flow analysis}

Marx and Engels were the first to use the concept of social metabolism in the social sciences. Their notion of metabolism "was molded by the biology of their times and popular writings from physiological materialists [...] who described metabolism as an exchange of matter between an organism and its environment" (Fischer-Kowalski, 1998, 64). As such, Marx and Engels' use of the term was meant to imply a relation of material exchange between human society and nature. According to Foster (2000, 158), Marx employed the term in two ways: "to refer to the actual metabolic interaction between nature and society through human labor", and in a wider sense to describe "the complex, dynamic, interdependent set of needs and relations brought into being and constantly reproduced in 
alienated form under capitalism". Marx and Engels did not attempt to analyze material and energy flow rates and there is debate about their openness to attempts to do so. In any case, after them, the concept of social metabolism - and more generally ecological thinkingwas scarcely developed by Marxists until the last quarter of the twentieth century.

The study of material and energy flows was developed outside of the Marxist tradition by precursors to the field of ecological economics. In Fischer-Kowalski's (1998) oft-cited intellectual history of MFA, Robert Ayres and Allen Kneese are credited for having "basically presented the full program of what in the 1990s was carried out as material flow analyses of national economies" $(1998,71)$. Their pioneering study in 1969 "not only set up an appropriate conceptual framework, but also arrived at reasonable empirical results" (1998, 73). It would take another twenty years, however, until the concept of social metabolism and corresponding methods for calculating the flow of materials would become widely accepted. ${ }^{1}$ During the 1990 s, an increasing number of studies were published to analyze the social metabolism of industrial societies, using different geographical units of analysis, epistemological frames, and methodological approaches (Fischer-Kowalski \& Hüttler, 1999).

From this work, some broadly accepted principles for economy-wide material flow accounting emerged and these were codified by the Statistical Office of the European Union in 2001 (EUROSTAT, 2001). They have been updated since then (EUROSTAT, 2018) and made applicable globally by Krausmann et al. (2015). They include accounting for the extraction of all types of biomass, fossil energy carriers, and minerals. Data sources include national statistical offices, international databases, and scientific reports. Standardized MFA begins by calculating the weight of raw materials extracted within national borders, called "domestic extraction". It also includes procedures for estimating the volume of imports and exports, in order to estimate the country's "physical trade balance". For the purposes of this investigation, however, only domestic extraction rates are calculated, as a first approximation to the country's growing social metabolism during the neoliberal era and because most SECs in Mexico revolve around extractive activities, as shown below.

Krausmann et al. (2009) have used standardized MFA to examine the evolution of the global economy's social metabolism during the twentieth century. Their findings indicate that material flow rates increased by a factor of eight over the course of the century, reaching 59 billion metric tons in the year 2005. This is approximately twice as fast as the growth of the world's population, which quadrupled during the same period. In their analysis, the global economy's social metabolism began to accelerate in the post-World War II period, and it has continued to grow since then in absolute terms, even though there has been a relative increase in the efficiency with which materials are used. According to Krausmann and his collaborators, the sharp increase in metabolic rates during the postwar period can be attributed mostly to increasing material consumption in the countries at the center of the world economy, where per capita resource use stabilized at high levels after 1970. Since then, and especially since the turn of the millennium, metabolic rates have been on the rise in China, India, and several Latin American countries. Their analysis, however, does not capture material flows from one region to another.

With this objective, several studies have observed significant changes in global patterns of material extraction and consumption since the 1990s, largely driven by high economic

\footnotetext{
1 To be sure, quantitative measurements of MFA are quite different from Marxist explanations of social metabolism, since they do not attempt to explain the implications of the changing social relations of production that occur with increasing rates of material flow.
} 
growth rates and rising material intensity in the Asian region, China in particular. In just two decades, China went from being a negligible importer of non-renewable resources to the largest in the world, followed by the United States, India, Brazil, and Russia (Muradian et al., 2012; Giljum et al., 2014). Materials extracted from Latin America continue to flow to the United States and Europe, but increasingly to China and other Asian countries (Dittrich \& Bringezu, 2010; Muradian et al., 2012; Giljum et al., 2014; Infante-Amate et al., 2020), including through increasing investments by Chinese companies in extractive activities in Latin America (Cypher \& Wilson, 2015). Infante-Amate et al. (2020, 196) suggest that these new material flow patterns "represent a turning point in the history of the global biophysical economy." At the same time, they suggest that the growing demand for materials in China and other Asian countries stems largely from the role they play as the "new workshops of the world", where primary goods are transformed into products that are eventually sold in rich countries (Infante-Amate et al., 2020, 196).

These studies point to the interconnectivity between the expansion of the extractive frontier in Latin America and the acceleration of the social metabolism of the world economy. With a view of Latin America, Martínez Alier and Walter (2016) use MFA (with reference to EUROSTAT, 2001) to calculate the rate of extracting materials from the region, observing that it increased by a factor of four between 1970 and 2008, reaching over 8 billion tons in the last year of their analysis. Further, they observe persistent and increasing physical trade deficits in Latin America during this period, characterized as "ecologically unequal exchange", in the terms conceptualized by Hornborg (1998).

As mentioned in the introduction, Mexico stands out in the Latin American region because its economy has not been "reprimarized" to the same extent as in South America (Cypher, 2010). ${ }^{2}$ Between 2000 and 2017, primary commodities represented only $21.4 \%$ of Mexico's total exports, compared to about $70 \%$ for Argentina, Colombia and Uruguay; over $80 \%$ for Chile and Peru, and over $90 \%$ for Bolivia, Ecuador and Venezuela in the same period. ${ }^{3}$ Mexican exports are dominated by manufactured goods produced in the maquiladora sector, especially automotive parts, electronics and electrical appliances. Although Mexico has signed over a dozen free trade agreements, about $80 \%$ of its exports go to the United States.

Tello (1996) argued that the exportation of manufactured goods from Mexico's maquiladora sector constitutes a form of exporting cheap labor, which is embodied in maquila products. This, combined with the massive flow of migrant workers to the United States, makes cheap labor Mexico's (and Central America's) most important export, according to Cypher (2010, 637), who goes so far as to suggest that "Central America and Mexico are actually caught in what might be termed 'sub-primarization"'. However, while cheap embodied labor is indeed exported from Mexico, so are large volumes of primary materials (González Martínez, 2007), which are also cheap insofar as transnational companies are able to more effectively externalize social and environmental costs south of the US border. Between 1970 and 2003, the weight of Mexico's exports grew from 14 million tons to 243 million tons, while imports went from 8.5 million tons to 185 million tons. (González Martínez, 2007), indicating a substantial increase in the country's physical trade deficit.

\footnotetext{
2 The "primarization" of South American economies is measured by Cypher (2010) in terms of value of primary commodities in the composition of a country's exports.

3 These figures are based on data obtained in April of 2019 from "Data and Statistics" made available by Economic Commission for Latin America and the Caribbean, through its database CEPALSTAT (www. https://www.cepal.org/en/datos-y-estadisticas).
} 
González Martínez (2007; see also González Martínez \& Schandl, 2008) provided the first economy-wide MFA for Mexico and the only one available until now. According to her calculations, the rate of extracting materials from Mexico increased from 349 million tons in 1970 to 1148 million tons in 2003, mostly due to a rise in mineral and fossil-fuel extraction. This article seeks to provide an updated analysis of Mexico's domestic extraction rates, to explain their tendency to rise as a consequence of neoliberal reforms and booming global demand for primary commodities, and to analyze the relation between increasing rates of material extraction and the proliferation of SECs.

\section{From state-led industrialization to neoliberal extractivism}

During the post-World War II period, the Mexican state regulated and controlled extractive activities to strategically provide raw materials for industrial development and to obtain foreign currency through the exportation of primary commodities (Tetreault, 2020). In the petroleum sector, PEMEX, the state-owned oil and gas company, held a monopoly over all facets of production, processing and distribution. At first, production was geared toward meeting the growing national demand for fossil fuels, but when huge offshore oil reserves were discovered in the mid-1970s, exports soared (Puyana Mutis, 2015). From that point on, the Mexican government became increasingly dependent on oil revenues to finance public expenditures (Colmenares, 2019).

The mining sector was controlled by foreign capital, mostly US, until a law was passed in 1961 to oblige all mining companies operating in the country to be at least 51\% Mexican owned. The country's Mining Law was modified again in 1976 to strengthen direct state participation, especially in the production of iron, copper and coal. By 1980, the Mexican state owned $15 \%$ of the country's mining property, private Mexican capital controlled $48 \%$, and foreign capital the rest (Urías, 1980, 957). The most significant increases in mineral extraction during the 1960s and 70s were in the subsectors with the most government involvement (iron, copper and coal), while the rates of extracting silver, lead and zinc practically stagnated (Delgado Wise \& Del Pozo Mendoza, 2005, 71).

The land reform process that had been initiated by the Mexican Revolution (1910-1920) progressed during the post-war period such that by the late 1970s approximately half of the country's territory was in the ejidal sector. Ejidos are formally owned by the State, with collective usufruct rights over specific territorial delimitations granted to peasant and indigenous groups. During the post-war period, the commercial agricultural production of ejidal producers was controlled by the state through an array of governmental agencies that provided seeds, credit, extension services, and guaranteed prices, ${ }^{4}$ with the objectives of achieving food self-sufficiency in basic grains and providing low-cost food to the urban working classes. At the same time, the Mexican state invested heavily in irrigation projects and funded the development of Green Revolution technology, mostly to the benefit of large private landowners who produced cash crops for export to the US (Hewitt, 1980). Under

\footnotetext{
4 The most important governmental agencies involved include the National Company of Popular Subsistence (CONASUPO), Mexican Fertilizers (FERTIMEX), the National Bank of Rural Credit (BANRURAL), and the National Seed Producer (PRONASE).
} 
these conditions, the volume of grains produced in Mexico grew from under 9 million tons per year in the early 1960 s to over 20 million tons per year in the early 1980 s. $^{5}$

In all, the rates of extracting materials from Mexico grew steadily during the post-war period, as quantified by González Martínez (2007) from 1970 onwards; and this trend coincided with the emergence of the country's first social conflicts with explicit ecological content. For example, in the southeastern state of Tabasco, 23 rural communities blocked access to PEMEX's wells in 1976 to demand compensation for petroleum contamination; and in the state of Oaxaca, 22 indigenous communities blocked highways and carried out protests in the early 1980s over logging (Flores et al., 1988). ${ }^{6}$ These types of conflicts would emerge throughout the country in the following years, as the Mexican economy was restructured in accordance with the principles of free trade, privatization and deregulation, leading to increasing rates of material extraction.

Mexico began the transition from state-led ISI to market-led development during the 1980 s, in the context of the debt crisis and the emergence of a new international division of labor. The year 1992 marked the turning point in unleashing private and foreign capital on Mexico's land and natural resources. In that year, the government of Carlos Salinas officially ended redistributive land reform and opened the door to privatizing the ejido. Salinas's government passed a new regulatory law for PEMEX to facilitate the company's restructuring in the quest for greater competitiveness and to allow for private sector participation in downstream activities (Colmenares, 2019). Salinas' government also made changes to Mexico's Mining Law to allow for the participation of 100-percent foreignowned companies, to eliminate limits on the territorial size of concessions, to extend the period of their validity from 25 to 50 years (renewable thereafter), and to give precedence to mining activities over all other use of the land. In addition, the National Water Law was established in 1992 to create institutional mechanisms for the exchange of usufruct rights over water resources and to create opportunities and incentives for private sector participation in the construction and operation of hydraulic infrastructure (Dávila Poblete, 2006). All of this culminated in the signing of the North American Free Trade Agreement (NAFTA) in December of 1992, which served to lock in neoliberal reforms and transfer legal matters concerning FDI to the supranational level.

The petroleum sector was further liberalized during Ernesto Zedillo's presidential term (1994-2000) to give private firms the opportunity to engage in the distribution and storage of natural gas. In addition, Zedillo's government launched an initiative to attract private investment in the construction of energy infrastructure, called Productive Infrastructure Projects with Deferred Impact (PIDIREGAS in its Spanish acronym). Presidents Vicente Fox (2000-2006) and Felipe Calderón (2006-2012), both of the conservative National Action Party (PAN), gave further impulse to the privatization agenda. Fox passed reforms to allow transnational companies to extract gas from the Burgos Basin in the northeast. Calderón's reforms allowed PEMEX to contract the services of transnational companies in the areas of exploration and production (Tetreault, 2020).

\footnotetext{
5 These figures are based on data obtained in June of 2020 from FAO's online database, FOASTAT (http:// www.fao.org/faostat/en/\#home), particularly the data on "Crops and Livestock Products", using the variable "Production quantity" of aggregated "crops primary".

6 It is important to note that the latter struggle was successful in wresting control from private and parastatal companies over the forests of ejidos and indigenous communities, eventually leading to the construction of ecologically and socially sustainable community-based forestry management by Zapotec communities in the Sierra Juárez of Oaxaca (Fuente Carrasco \& Barkin, 2011).
} 
The country's petroleum sector was opened completely to private and foreign investment in December of 2013, as part of the energy reform implemented by the government of Enrique Peña Nieto, of the Institutional Revolutionary Party (PRI). This reform modified Article 27 of the Constitution to allow private and foreign companies to invest in every phase of oil and gas exploitation. Petroleum is still technically owned by the state while still in the ground, but it can be appropriated at the wellhead by private firms, who can also book proven reserves. Between 2014 and 2018, three auctioning rounds took place, resulting in the establishment of 111 contracts with private oil and gas companies. ${ }^{7}$

In the mining sector, the privatization of parastatal mining companies during the first three years of Salinas' presidency served to transfer the country's mining infrastructure and proven mineral reserves at a low cost to well-connected Mexican businessmen (Delgado Wise \& Del Pozo Mendoza, 2005). As the mining sector opened completely to FDI, foreign mining capital, especially Canadian, took the lead in exploration, going after mostly gold and silver. In this way, foreign companies have been driving the expansion of the mining frontier in Mexico (Tavera Fenollosa, 2019). Between 1994 and 2018, the federal government granted over 45 thousand mining concessions to private companies, covering an area of approximately 105 million hectares, equivalent to over half of the country's territory.

As for the agricultural sector, its restructuring began in the context of the debt crisis. The federal government under De la Madrid (1983-1988) deregulated agricultural imports and slashed funding for integrated rural development programs, as well as supply-side subsidies meant to achieve food self-sufficiency. During Salinas' presidency (1988-1994), trade in agro-food products was further liberalized. NAFTA established a framework for phasing out remaining tariffs and quotas in the agricultural and forestry sectors over the course of 15 years. Salinas also set in motion the elimination of guaranteed prices for agricultural products, the shrinking of subsidized credit for farmers, the dismantling of the state-owned grain handling company (CONASUPO), and the privatization of the state-owned agrochemical producer (FERTIMEX). All of this paved the way for large national and transnational agro-food corporations to take control of the main agriculture-based value chains in Mexico, including through the renting of land from ejidos and private small-scale farmers (Robles Berlanga, 2012).

To be sure, neoliberal structural adjustments in Mexico led, not only to the expansion and intensification of extractive activities as analyzed below, but also to diverse forms of resistance and adaptation by peasant and indigenous groups. These include the Zapatista uprising in 1994 and subsequent efforts in indigenous zones throughout the country to construct autonomous forms of self-governance, as well as the struggles of peasant organizations for better conditions of production through government support of small-scale agriculture (Bartra, 2019).

\section{The social metabolism of environmental conflicts}

Several authors have pointed to a correlation between the increasing social metabolic exchange between human societies and the natural environment and the rise in the number of SECs (Martínez Alier, 2007; Russi et al., 2008; Martínez Alier et al., 2010; Vallejo,

\footnotetext{
7 Information about these contracts and the companies involved can be found on the website of the Mexican Petroleum Fund (https://www.fmped.org.mx).
} 
2010; Muradian et al., 2012; Martínez Alier \& Walter, 2016; Delgado Ramos, 2017; PérezRincón et al., 2018). Martínez Alier was the first to hypothesize a causal relation in this direction, building on his previous work on ecological distribution conflicts and the environmentalism of the poor, the latter conceptualized as struggles to protect the material basis of subsistence livelihoods (Martínez Alier, 2011). In his formulation (2007, 62), there exists a "three-tier relation" between the social metabolism of human economies, ecological distribution conflicts, and alternative "languages of valuation". In this relation, economic and population growth increase humanity's social metabolism with nature; ecological distribution conflicts stem from the unjust allocation of the economic benefits and the social costs of extracting resources and polluting; and these conflicts are expressed discursively by the actors involved through framings that exhibit incommensurable valuations of natural resources and environmental services.

Martínez Alier (2007) and his co-authors (Martínez Alier \& Walter, 2016; Martínez Alier et al., 2010) recognize that not all SECs are born from the immediate metabolic needs of industrial development. The demand for gold, for example, arises largely from the search for lucrative speculative investments. Although trading in futures has brought speculative investment to all primary commodities, "[t]he fact remains that both energy-carriers (coal, gas, oil) and metallic minerals are inputs for the industrial economy and that their use, in total, grows more or less in proportion to the growth of the economy" (Martinez Alier and Walter, 2016, 60). ${ }^{8}$ Moreover, as Muradian et al. (2012) acknowledge, declining ore grades and the exhaustion of conventional hydrocarbon reserves have led to the development of environmentally aggressive technologies to exploit marginal reserves (for example, open-pit mining and fracking); and they have led to the expansion of extractive activities to fragile ecosystems and territories inhabited by indigenous groups and peasants, thereby creating conditions that are conducive to SECs.

This investigation focuses on SECs on the extractive frontier because this is where most of these conflicts occur in Mexico. However, there are many others that occur at distinct moments of material exchange in the social metabolic relation between capitalist development and the non-human environment, including the processing of materials into goods with exchange value, their circulation, and the excretion of wastes (González de Molina $\&$ Toledo, 2011). Accordingly, aside from extractive activities per se, there are SECs in Mexico around nuclear facilities, waste management, water pollution, infrastructure development, and industrial activity.

SECs involve struggles by organized groups against extractive activities and the dispossession of common goods. They go beyond issues of material distribution to include greater participation in decision-making and recognition of cultural differences (Schlosberg, 2007). In Mexico, as in other parts of the world, SECs typically pit affected popular groups from affected rural communities (women, smallholder farmers, indigenous people, and workers) who struggle to defend their territories, water, traditional livelihoods, culture, and collective well-being; against governmental agencies and private companies that promote extractive activities in the name of development (Tetreault et al., 2018). The former frequently find allies in civil society, including non-governmental organizations, university groups, collectives, religious groups, artists, and activists. Of course, the state is not monolithic and some state agencies may support—or at least rule in favor of-environmentally affected people organized in resistance to environmentally destructive projects (Silva et al.,

${ }^{8}$ Technically, coal, gas and oil are not "energy carriers" (like heat or electricity), but rather energy sources. 
2018). In these ways, it is possible to speak of polyclass movements (Svampa, 2015), led by peasant and indigenous groups (Veltmeyer \& Petras, 2014), in defense of territory and common goods (Navarro, 2015).

From a different angle, it is important to acknowledge that not all SECs involve organized groups that struggle to oppose the imposition of socio-ecologically destructive activities; there are also local struggles that seek to negotiate more benefits and lower costs for affected populations in exchange for their going along with such activities. Along these lines, Gudynas $(2014,79)$ observes that there are "conflicts that point to different forms of coexistence with extractivist enterprises and others that include demands to reject them". In Mexico's mining sector, it has been observed that resistance struggles of opposition are much more likely to involve indigenous groups (Pérez Jiménez, 2014) and to occur in areas without a history of mining (Tavera, 2019; Martínez Romero, 2020). On the other hand, not all SECs can be easily categorized according to this opposition-versus-negotiation dichotomy, among other reasons because-within a given territory-positions of opposition, negotiation and collaboration can coexist in tension vis-à-vis ecologically destructive projects (Uribe et al., 2020). Also, the positions of affected groups can change over time, especially when contested projects get underway or have finished, after which negotiation becomes a more likely posture (Tetreault, 2015).

\section{Method and sources of data}

As mentioned above, this investigation seeks to estimate the rates of extracting minerals, fossil fuels, and biomass from Mexican territory as a first approximation to quantifying the social metabolic intensity of extractive activities during the neoliberal era. For this purpose, it employs standardized procedures to calculate domestic extraction from 1990 to 2018. Domestic extraction refers to "the purposeful extraction or movement of natural materials by humans or human-controlled means of technology (i.e., those involving labour)" from a given territory for economic purposes (Krausmann et al., 2015, 11; EUROSTAT, 2018, 19). Unused materials, which are extracted or moved without entering into economic processing, are not included; for example, overburden in mining and residues from agricultural production that are burned or ploughed into the soil. Water is excluded or kept apart, mostly because the volumes of water used in extractive activities (especially agriculture) are so large that they tend to virtually drown the analysis of other material flows. ${ }^{9}$

The procedures for calculating domestic extraction rates have been standardized by EUROSTAT $(2001,2018)$ and these have been adapted for global application by Krausmann et al. (2015), who provide an array of coefficients and conversion factors for regions outside of Europe, as detailed below. Some conversion factors were also taken from González Martínez (2007), particularly for metal-ore extraction, since these are considered to be more accurate for Mexico's mining sector. No attempt has been made to aggregate Mexico's domestic extraction rates. In part, this has to do with the high degree of

\footnotetext{
9 Water extraction rates and related analysis have not been included in this investigation, mostly because of space limitations. To be sure, water flows through extractive activities and is therefore at stake in one way or another in the SECs around these activities. There are also numerous SECs in Mexico around large dams, water contamination and the over-exploitation of aquifers, as indicated by the databases presented below.
} 
uncertainty regarding construction minerals; also it is because the focus of this investigation is on the relation between evolving extraction rates and related SECs in each metabolic sector.

The general procedure for estimating domestic extraction rates of minerals and construction materials is straightforward since no conversion factors are necessary. As Krausmann et al. $(2015,40)$ note, the rate of extracting minerals is commonly reported on the national level with high reliability on industrial minerals and metal ores, but much less so for bulk minerals like sand and gravel. This is the case for Mexico, where mineral extraction rates are published annually in the Statistical Yearbook of Mexican Mining, produced by Mexican Geological Services (SGM), a branch of the Ministry of Economy. The SGM employs ad-hoc data-gathering procedures to estimate the rates of extracting construction minerals. This is because the extraction of construction material is not bound by federal law. The firms that extract these materials do not require a concession and they are not required by law to report to the Ministry of Economy on their extraction rates. Therefore, SGM's reporting draws from a variety of alternative sources, including diverse governmental agencies and information solicited from the firms themselves. However, because these firms have been reluctant to report on extraction rates in recent years, citing concerns over security, since 2014 the SGM's estimates have been based mostly on information drawn from the Banks of Materials Inventory managed by the Ministry of Communication and Transport, with additional information obtained from the Ministry of Water's Public Registry of Water Rights, which includes certificates for permission to extract stone materials. ${ }^{10}$ As illustrated in the next section, this shift in data collecting procedures resulted in a dramatic increase in the estimates for extracting construction materials from 2013 to 2014.

SGM's annual reports contain reliable data on the extraction of metallic ores. According to standardized MFA, estimates for rates of extracting metallic ores are obtained for the total amount of crude mineral that is submitted to the first processing step, known as "runof-mine production". This requires introducing conversion factors to reflect average ore grades and to take into consideration coupled production. For the purposes of this investigation, the conversion factors used by González Martínez (2007, 22) were employed, and the same measures for taking account of coupled production. SGM's data covers gold, silver and 12 industrial metals.

As for fossil fuels, the standardized method for calculating extraction rates is straightforward and based on reliable national statistics for crude oil and natural gas, although less so for coal. The yearly extraction rates of crude oil and natural gas were obtained from INEGI (2015) and PEMEX (2018). SGM's Statistical Yearbook of Mexican Mining provides data on the yearly rate of extracting coal. However, contradictory data published in recent editions of the same yearbook led to the need to solicit information from Mexico's Ministry of Economy in order to determine extraction rates of coal from 2010 to $2018 .^{11}$

Turning now to biomass extraction, the standardized method for calculating its rate involves taking into consideration primary crops, fodder crops, crop residues, grazed biomass, wood extraction, and fish capture (Krausmann et al., 2015). The sources of data and

\footnotetext{
10 This information was provided by the Ministry of Economy on 17 June 2020 in response to a request for access to information (number 0001000103820) through the National Transparency Platform (https://www. infomex.org.mx).

11 Information request number 1000110321 sent on 2 June 2021 to the Ministry of Economy via the National Transparency Platform (https://www.infomex.org.mx).
} 
general procedures used in this investigation for each of these categories can be summed up as follows:

(1) Data on primary crops was obtained from the Food and Agriculture Organization's (FAO) online database, FAOSTAT, which covers 115 crops grown in Mexico.

(2) Data on fodder crops was obtained from Mexico's Ministry of Agriculture's System for Agrofood Information Consultation (SIACON). In accordance with standardized procedure (Krausmann et al., 2015, 16), fodder crops reported in fresh weight were converted to the equivalent of $15 \%$ moisture content.

(3) The weight of crop residues was calculated using grain-to-straw ratios and harvest factors to estimate the percentage of primary crops typically left behind. These were obtained from Krausmann et al. (2015, 28).

(4) Of the different standardized ways to calculate grazed biomass, the one used in this study extrapolates from data available from SIACON on the domestic production of animal products (meat, milk and eggs). This method requires the use of conversion coefficients to calculate the amount of feed energy required to produce each type of primary animal product, as well as factors to account for the share of roughage in total feed energy. These were obtained from Krausmann et al. (2015, 33).

(5) Data on wood extraction, including fuel-wood, was obtained from FAOSTAT, which provides figures in cubic meters. These were converted to tons at $15 \%$ moisture content using the procedure outlined by Kruasmann et al. (2015, 35).

(6) Data on the weight of live fish capture was obtained from the federal government's Statistical Yearbook of Aquaculture and Fisheries, years 1991 to 2019.

Further, this investigation seeks to juxtapose domestic extraction rates with tendencies in the emergence of SECs. For this purpose, three economy-wide inventories of SECs in Mexico are available. First, by participating in assemblies that bring environmentally affected people together and through a systematic revision of newspaper articles from May 2009 to May 2011, Paz (2012) detected 95 cases of SEC in Mexico, of which 39\% have to do with water, $25 \%$ with agricultural land and territories, and $15 \%$ with protected areas. Two years later, her inventory registered 133 cases $(\mathrm{Paz}, 2014)$ and by October of 2020, it had reached almost $300 .^{12}$. Second, based on a review of relevant reports in the newspaper La Jornada between September 2009 and March 2014, Toledo et al. (2015) detected 298 SECs. By early 2016, their count had reached 420, and their most recent estimate points to 560 conflicts, detected between 2012 and 2017, revolving around mining (173), water (86), energy (74) tourist developments (49), urban expansion (38), forestry (37), agriculture (35), hazardous wastes (34), highways (16), fishing (10), and biotechnology (8). ${ }^{13}$ As this breakdown indicates, extractive activities are the most common immediate cause of SECs in Mexico. Third, the collaborative project EJAtlas registered 172 social environmental conflicts in Mexico by August of 2021, out of a total of 3,509 globally. Of the cases

\footnotetext{
12 This estimate of "almost 300" social environmental conflicts, was mentioned during Fernanda Paz's presentation titled "Conflictos socioambientales y luchas de defensa territorial en México. Una Ventana de esperanza ante a la crisis multiple", on Octobre 22, 2020, as part of Tercer Coloquio Internacional de Sociedades Sustentables, Maestría en Sociedades Sustentables, Universidad Autónoma Metropolitana, campus Xochimilco. https://www.facebook.com/maestriasociedadessustentables/videos/771147767065045/.

13 https://www.mexicoambiental.com/investigadores-de-la-unam-revelan-mas-de-500-conflictos-ambie ntales-en-mexico-y-construye-mapa-que-los-georeferencia-y-categoriza/.
} 
registered in Mexico, almost two-thirds have to do with mining, water, fossil fuels, or biomass. The information registered in EJAtlas indicates that $91 \%$ of SECs in Mexico began after 1990 and $85 \%$ after 2000 .

The EJAtlas inventory is especially useful for this investigation, since it makes available on the Internet (www.ejatlas.org) extensive information about each case, with classifications by metabolic sector. It also provides information on the status of each conflictive project, thereby providing an indicator of the degree to which resistance struggles have contributed to countering the tendency for material extraction rates to increase. Of the 172 SECs registered in Mexico, 21 revolve around projects that have been stopped.

The EJAtlas database has been constructed by a network of academic institutions, activist groups, and individual researchers, who have collaborated with an editorial team at the Autonomous University of Barcelona, led by Joan Martínez Alier. The method used to detect and register cases is outlined in detail by Temper et al. (2015). Data is collected through participatory action research and from a variety of sources; entries are geo-located on a world map; and the editors fact-check before publishing a case online. Although this method does not necessarily provide a comprehensive coverage of SECs (since registered cases depend on the focus of individual collaborators), it does lend itself to constructing a database with in-depth information that is systematized to facilitate analysis.

Similarly, the project "Conversing with Goliath", led by Gisela Zaremberg from the Latin American Faculty of Social Sciences (FLACSO Mexico) and Valeria GuarnerosMeza from the University of Montfort, has created a georeferenced database of information on conflicts in Mexico in the mining and energy sectors. ${ }^{14}$ Through a systematic review of newspaper reports from all media sources in Mexico between January 2006 and December 2019, this project registered a total of 336 conflicts: around mining (155), oil fields (75), hydroelectric dams (49), wind farms (40), and pipelines (17). The information in this database includes the geographical location of each conflict, the names of the private companies and state agencies involved, a short description of conflictive issues, the demands of affected groups, and reports on incidents of violence.

Before moving on to the next section, it is important to note that all four of the databases mentioned above indicate that SECs are on the rise in Mexico and that the great majority of these conflicts stem from extractive activities.

\section{Domestic extraction rates and related conflicts}

Figure 1 presents the total volume of non-metallic minerals extracted from Mexico from 1990 to 2018, according to the data provided by SGM. The first feature that stands out is the enormous increase in the estimates for extracting construction materials from 2013 to 2014, especially for sand, limestone, basalt, and stone materials. As mentioned above, this corresponds to a shift in data collecting procedures. As such, there are essentially two time series of data brought together in the same figure: from 1990 to 2013, and from 2014 to 2018. Both indicate a trend for extraction rates to increase over time. In all, based on SGM data, the rate of extracting the 45 most important non-metallic minerals from Mexico grew steadily between 1990 and 2013, from 133.4 million metric tons to 347.5 million tons; then

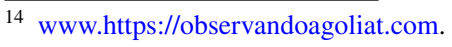




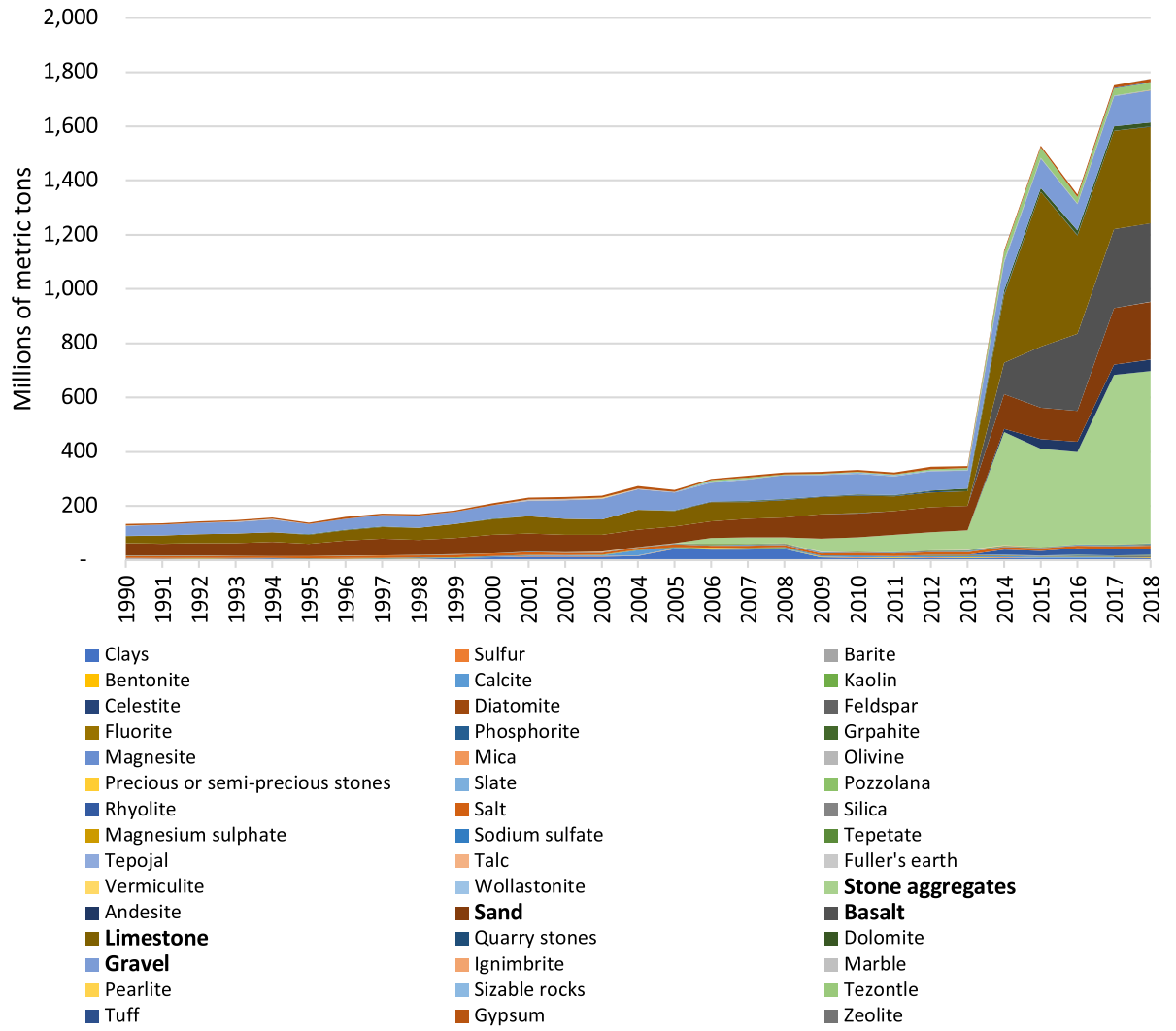

Fig. 1 Non-metallic minerals extracted from Mexico, 1990-2018 (millions of metric tons). Source: Author's elaboration based on data from SGM's Statistical Yearbook of Mexican Mining, years 1991 to 2019

it jumped to 1143.6 million tons in 2014 and continued to grow to 1774.7 million tons by 2018.

Even though the extraction of construction materials has grown considerably in Mexico since the 1980s to supply cement and other materials for rapid urban expansion, it is relatively understudied (Fry, 2011). In one of the only investigations on the matter, Fry (2011) analyzes tepetzil extraction in the Perote Valley of central Veracruz, shedding light on why farmers-who were initially reluctant to sell extraction rights-were induced to do so in the context of diminishing returns to agriculture under NAFTA. Of the 40 SECs around mining in Mexico registered by EJAtlas, only five have to do with large projects to extract non-metallic minerals: US-based Odyssey Marine Explorations' project to extract underwater phosphate deposits off the coast of Baja California Sur; Chinese company Gangfeng's project to mine lithium in Sonora; Canadian-based Blackfire's barite mine in Chiapas; limestone extraction around the city of Monterrey by Mexican company CEMEX and others; and limestone extraction in Quintana Roo by a subsidiary of US-based Vulcan Materials. The Ministry of Economy (Secretaría de Economía, 2018, 12) suggests that conflicts are widespread between the firms that extract construction minerals and the ejidos from which they rent land to do so. However, these conflicts tend to be confined to the local 


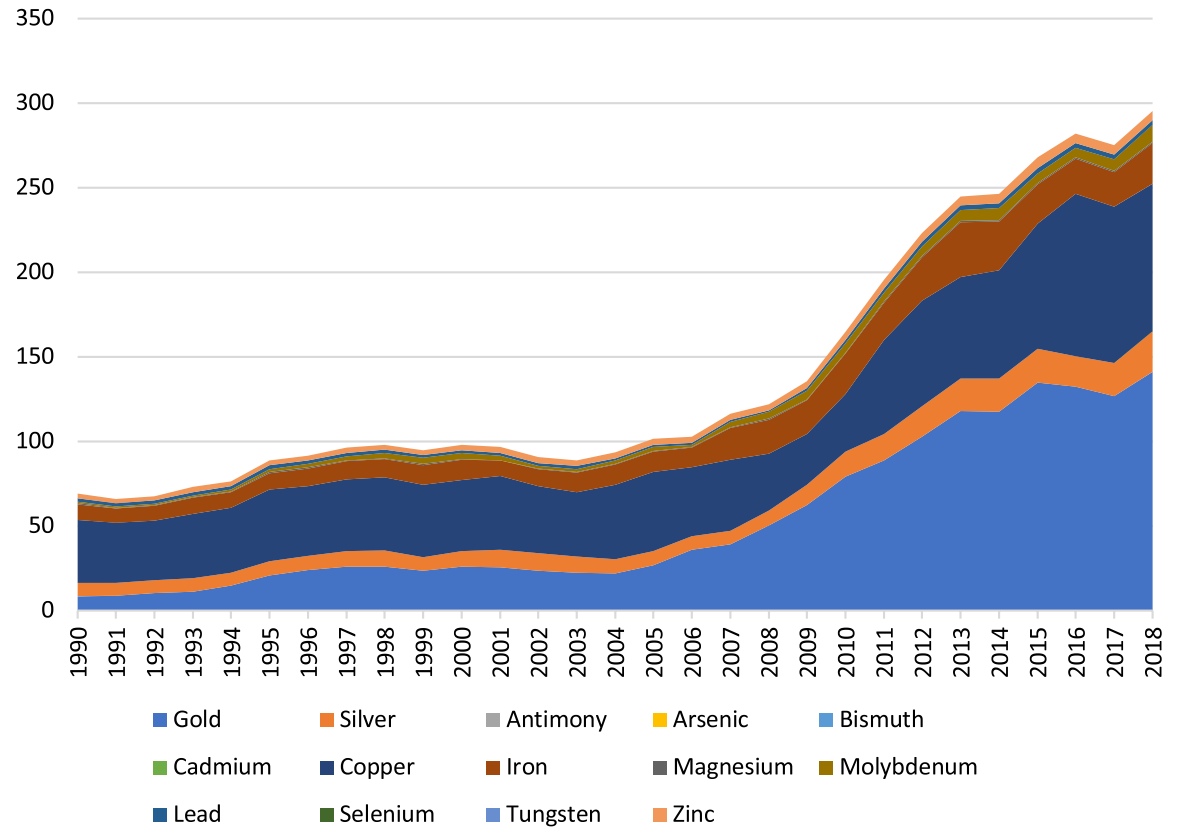

Fig. 2 Metallic ores extracted from Mexico, 1990-2018 (millions of metric tons). Source: Author's elaboration based on data from SGM's Statistical Yearbook of Mexican Mining, years 1991-2019

level and have not led to the kind of organized and sustained resistance that has emerged to contest large open-pit mines for extracting metallic ores.

Figure 2 presents the total volume of metal ores extracted from Mexico from 1990 to 2018. As can be observed, the general tendency is one of moderate growth from the early 1990s to 2006, from under 70 million tons to just over 100 million tons. After 2006, in the context of a primary commodity boom that saw mineral prices soar until 2013 before falling back to levels still well above those of the early 2000s, the rate of extracting metallic ores from Mexico climbed steeply, reaching its highest level in 2018 at almost 300 million tons.

The largest contributor to this increase is from gold extraction, which increased by a factor of more than five between 2005 and 2018. Copper is the second largest contributor. The rate of extracting copper stagnated from the mid-1990s to 2007. Then it dropped until mid-2010 because of a labor strike at the Buenavista mine in Sonora, which shut down the largest copper mine in the country for a period of almost three years. The mine reopened in June of 2010, after federal police violently dislodged striking miners, and it was expanded thereafter, driving up extraction rates on the national level.

Mining is the immediate cause of more SECs in Mexico than any other activity, according to the inventories compiled by Toledo et al. (2015), EJAtlas, and Conversing with Goliath. Thirty-five of the 40 mining conflicts registered in EJAtlas deal with metallic ores. Only five of these began before the year 2000. Of the 155 mining conflicts detected by Conversing with Goliath, 97 include demands to protect the environment and 36 are centered on labor rights. Other demands have to do with territorial organization (45), pecuniary assets (33), corruption (26), and insecurity and organized crime (22). In all, local groups struggling against mining projects in Mexico have gained organizational strength 


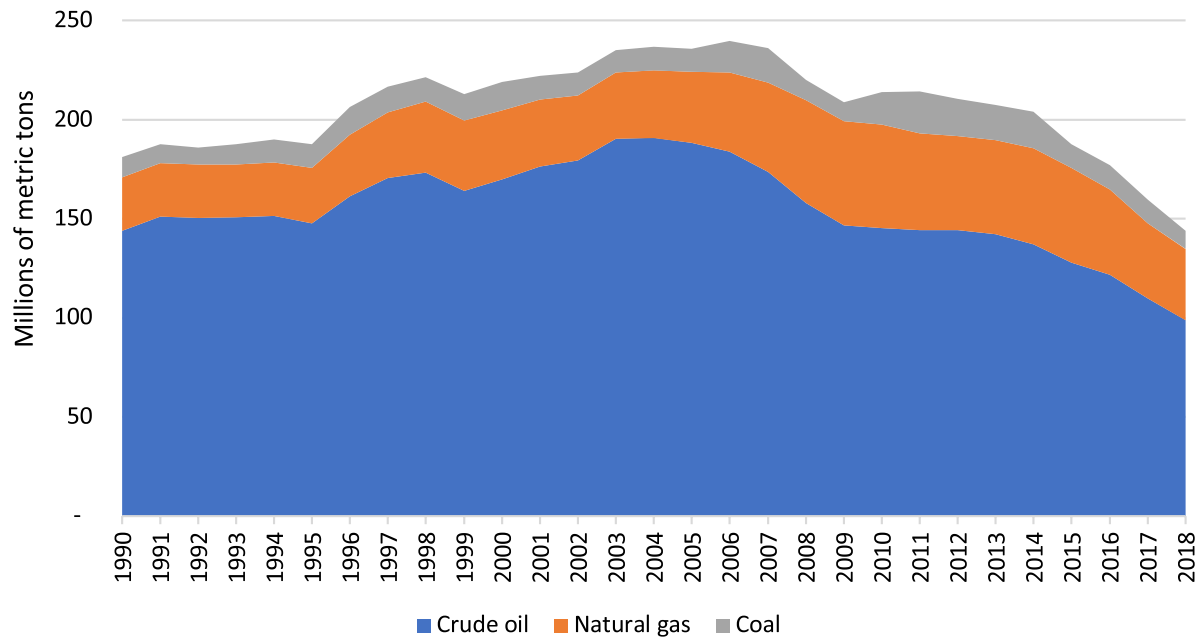

Fig. 3 Fossil fuels extracted from Mexico, 1990-2018 (millions of metric tons). Source: Author's elaboration based on data from INEGI (2014) for crude oil and natural gas from 1990 to2013; PEMEX (2018) for crude oil and natural gas from 2014 to 2018; SGM's Statistical Yearbook of Mexican Mining (from 1991 to 2019), for coal from 1990 to 2009; and information received from Mexico's Ministry of Economy for coal from 2010 to 2018

since the 1990s, by building networks among themselves and with their allies on the regional, national and international levels (Delgado Ramos, 2017). An important landmark in this process was the creation of the Mexican Network for People Affected by Mining (REMA) in June of 2008.

Figure 3 shows the rate of extracting fossil fuels from Mexico from 1990 to 2018. The graph indicates an upward trend between 1990 and 2006, during which the rate of extracting fossil fuels went from 181 to 240 million tons. Then, from 2007 to 2018 the tendency is one of steady decline, falling to 144 million tons in the last year of analysis. This pattern of fossil fuel extraction can be understood as the result of a deliberate strategy by successive federal governments since the 1980s to accelerate crude-oil extraction, while underinvesting in exploration, thereby creating conditions conducive to carrying out neoliberal reforms in the petroleum sector. Along these lines, the PIDIREGAS scheme was employed in the late 1990s to procure private investment in the construction of an industrial plant on the coast of Campeche for the purpose of injecting nitrogen into Cantarell, the country's most important oil field. In this way, the rate of extracting crude oil from Mexico's largest offshore reserve was continuously accelerated for 15 years, before beginning its ineluctable decrease in 2005, drawing down the national rate of crude oil extraction along with it. The relatively small increase in natural gas and coal extraction between 2005 and 2006 served to postpone the peak of total fossil-fuel extraction for two years.

In spite of decreasing rates of extracting fossil fuels, the number of related SECs around hydrocarbon extraction appears to have increased over the past two decades. Of the 27 cases of conflict around fossil fuels and climate justice registered by EJAtlas, only three began before the year 2000. Paradoxically, this stems in part from dwindling reserves, which has encouraged the expansion of the oil-and-gas frontier toward 


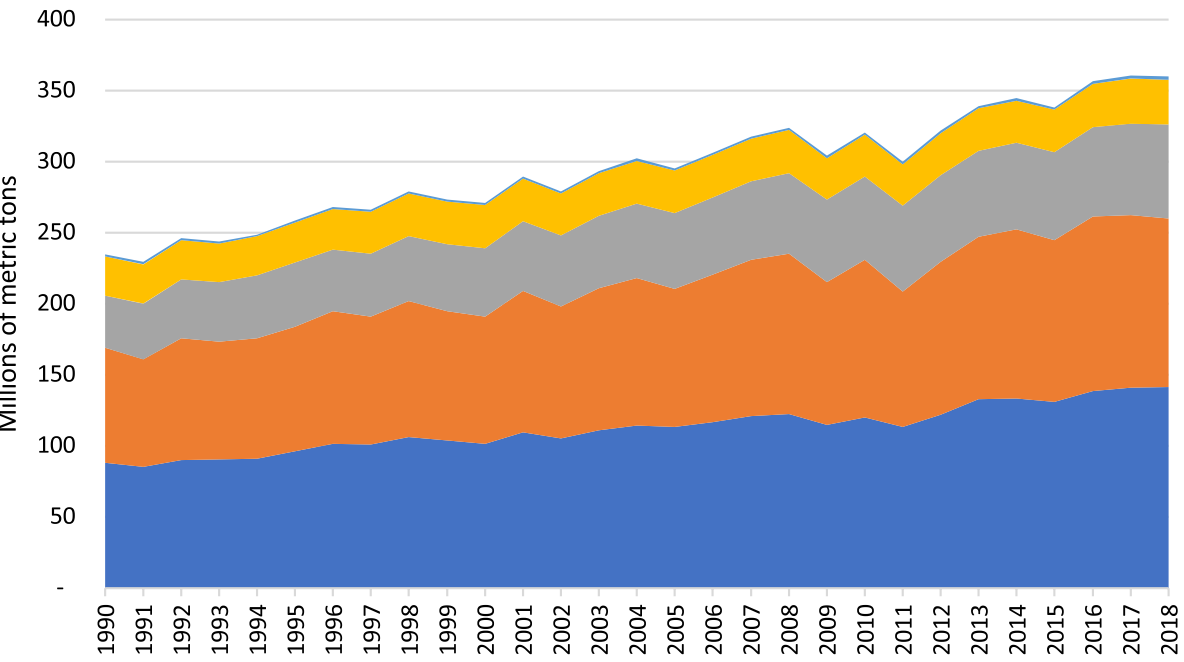

- Primary crops $\square$ Crop residues $\square$ Fodder crops and grazed biomass $\square$ Wood $\square$ Fish capture

Fig. 4 Biomass extracted from Mexico, 1990-2018 (millions of metric tons). Source: author's elaboration based on data from FAOSTAT for primary crops, crop residues and wood; SIACON data for Fodder crops and grazed biomass; and the Mexican government's Statistical Yearbook of Aquaculture and Fisheries, years 1991 to 2019 , for fish capture

unconventional reserves, including shale gas that requires fracking in arid regions of the northeast. In Mexico, exploration for unconventional gas began in the early 2000s, with some sporadic hydraulic fracking taking place since 2003 (Silva Ontiveros et al., 2018). Opposition to the use of this technology, which consumes and contaminates large quantities of water, has grown since the energy reform was passed in 2013. That year, the anti-fracking movement coalesced in the creation of a national-level network organization called the Mexican Alliance against Fracking, which brings together 40 civil society organizations from different parts of the country.

The project Conversing with Goliath registered 75 conflicts around petroleum extraction and 17 over pipelines. All of the conflicts around fossil-fuel extraction except nine involve PEMEX, while only two of the contested pipelines are owned and operated by the country's state-owned petroleum company. In all, 61 of the conflicts around the extraction and transportation of fossil fuels entail demands to protect the environment. Other demands deal with pecuniary assets (in 33 cases), labor rights (19), territorial regulation (17), inadequate consultation or lack thereof (13), insecurity and organized crime (13), and corruption (12).

Figure 4 presents estimates on the rate of extracting biomass from Mexico, from 1990 to 2018. As can be observed, the general tendency is one of continuous increase, from 235 million tons in 1990 to 360 million tons in 2018, with primary crops accounting for the largest share, residues the second, and fodder crops and grazed biomass, in third place. The relative importance of crop residues, which in most countries accounts for less biomass extraction than fodder crops, has to do with the large share of Mexico's agricultural product represented by maize, sugarcane and sorghum, which are crops that leave behind high volumes of residues for feed. 
To be sure, Mexico's agricultural sector has experienced profound changes during the neoliberal era. One of them has to do with the increasing importance of livestock. According to Róbles Berlanga $(2017,9)$ the production of chickens, hogs and cattle and their derivatives increased by more than 300\%, 100\% and 60\% respectively between 1980 and 2016. This has implied dedicating large areas of agricultural land to producing animal feed, equal to about $40 \%$ of the total harvested area in 2016 (Róbles Berlanga, 2017, 9). As illustrated in Fig. 4, the volume of fodder crops and grazed biomass extracted from Mexico grew from 36.7 million tons in 1990 to 66 million tons in 2018.

Another important trend in the neoliberal era has been the increasing production of fruits and vegetables, largely for export. According to FAOSTAT data, the volume of primary fruits and vegetables produced in Mexico more than doubled between 1990 and 2018, growing from 15.8 to 39 million tons in 2018. Mexico's production of maize and other cereals also grew considerably during this period, from 25.6 to 36.1 million tons. However, this was not enough to meet domestic demand, resulting in the need to import growing volumes of basic grains from the United States. In this way, Mexico's commercial balance of trade in agro-food products was negative until 2015, especially during the food crisis of 2007-2008. Since then, the value of agro-food exports has increasingly exceeded that of imports, driven by growth in the exportation of high-value products such as tequila, beer, berries, avocados, tomatoes, and other fruits and vegetables. The degrading impacts of these tendencies on agri-systems and human health have been well documented (González, 2019).

EJAtlas has registered 14 biomass and land conflicts in Mexico. Half of these center on defending forests. Others are against the planting of transgenic maize and soybeans, industrial hog farms in the Yucatan peninsula, and intensive fruit production (strawberries, blueberries and avocado) in the state of Michoacán. Only one of the 14 biomass and land conflicts registered by EJAtlas began before 1990: the struggle of the Tarahumara people in Chihuahua against the deforestation of their territories. It is noteworthy that, even though wood extraction accounts for only 10\% of total biomass extracted from México between 1990 and 2018, it is the source of the most SECs in the broader category of biomass, not only according to EJTAL's inventory, but also to the one compiled by Toledo et al. (2015). Conflicts around wood extraction stem from the relatively high value of forestry products and the dynamics of illegal logging in Mexico by armed groups associated with drug cartels, leading some rural communities to organize in defense of their forest resources, territories, and security (Guillén, 2016).

On another front, peasant organizations in Mexico have forged alliances with environmentalists and research centers to build a broad-based movement against the use of genetically modified seeds and to protect the country's biocultural diversity through agroecology (Toledo \& Barrera Bassols, 2017). This has not only resulted in important legal victories to stop the planting of genetically modified corn and soybeans, it has also manifested in local-level projects in different parts of the country to conserve landrace variety seeds, promote small-scale organic agriculture, recuperate traditional agro-ecological knowledge, and build on it through experimentation and farmer-to-farmer technology transfers.

\section{Conclusions}

This investigation has found that the rates of extracting minerals, metallic ores, and biomass from Mexico have increased dramatically from 1990 to 2018. And it found that the rate of extracting fossil fuels accelerated during the 1990s, peaked in 2006, and has declined since 
then because of the exhaustion of the country's most important offshore oil reserves. The analysis indicates that the overall tendency to accelerate domestic extraction rates in Mexico has been made possible by the neoliberal reforms that were implemented from 1992 onward to give private and foreign capital greater access to the country's land and natural resources. As extractive activities expanded and intensified throughout the country from the 1990s onward, local resistance emerged with greater frequency and network organizations have been built to bring them together. Basically, this is because the expansion of the extractive frontier wreaks environmental havoc on the territories of directly affected rural communities. In some of these, local inhabitants have organized and built alliances to defend their territories, traditional livelihoods, and cultures. In others, they have organized to negotiate better terms for accepting extractive projects.

While the empirical evidence presented in this analysis suggests that the expansion and intensification of extractive activities have created conditions that are conducive to the multiplication of SECs, this is not to say that the relation between rising extraction rates and increasing frequency of SECs is automatic or in direct proportion to the volumes of materials extracted. A case in point is Mexico's forestry sector, which is characterized by a high number of SECs, even though it contributes relatively little to the country's overall biomass extraction. Also, SECs can multiply even when overall extraction rates are declining, as illustrated by Mexico's petroleum sector, where resistance has emerged to fracking. After all, the rate of extracting materials is just one factor in a complex social metabolic relation of capitalist development in specific territories. Many other factors come into play in determining the severity of social-environmental impacts, local awareness of them, and the conformation or not of collective agencies of resistance. Where resistance does emerge, it can contribute to slowing down material extraction rates and to constructing more sustainable metabolic relations on the local level.

Acknowledgments The author is the recipient of a research grant (A1-S-21674) from Mexico's National Council of Science and Technology (Consejo Nacional de Ciencia y Tecnología - CONACYT) and Ministry of Public Education (Secretaría de Educación Pública - SEP), through their funding program for Basic Scientific Research 2018 (Investigación Científica Básica 2018).

Funding Consejo Nacional de Ciencia y Tecnología, A1-S-21674, Darcy Tetreault.

Open Access This article is licensed under a Creative Commons Attribution 4.0 International License, which permits use, sharing, adaptation, distribution and reproduction in any medium or format, as long as you give appropriate credit to the original author(s) and the source, provide a link to the Creative Commons licence, and indicate if changes were made. The images or other third party material in this article are included in the article's Creative Commons licence, unless indicated otherwise in a credit line to the material. If material is not included in the article's Creative Commons licence and your intended use is not permitted by statutory regulation or exceeds the permitted use, you will need to obtain permission directly from the copyright holder. To view a copy of this licence, visit http://creativecommons.org/licenses/by/4.0/.

\section{References}

Arsel, M., Hogenboom, B., \& Pellegrinia, L. (2016). The extractive imperative in Latin America. The Extractive Industries and Society, 3, 880-887. https://doi.org/10.1016/j.exis.2016.10.014

Bartra, A. (2019). Los nuevos herederos de Zapata. Un siglo en la resistencia 1918-2018. Fondo de Cultura Económica.

Colmenares, F. (2019). Despojo, resistencia y corrupción. México en los ciclos del precio del petróleo. Plaza y Valdes. 
Cypher, J. (2010). South America's commodities boom: Developmental opportunity or path dependent reversion? Canadian Journal of Development Studies, 30(3-4), 635-662. https://doi.org/10.1080/ 02255189.2010.9669319

Cypher, J., \& Wilson, T. D. (2015). Introduction. China and Latin America processes and paradoxes. Latin American Perspectives, 42(6), 5-26. https://doi.org/10.1177/0094582X15599958

Dávila Poblete, S. (2006). El poder del agua, ¿Participación social o empresarial? México, experiencia piloto del neoliberalismo para América Latina. Itaca.

Delgado Ramos, G. C. (2017). Del extractivismo minero en México, la defensa del territorio y las alternativas. Voces En El Fenix, 60, 72-79.

Delgado Wise, R., \& Del Pozo Mendoza, R. (2005). Mexicanization, privatization, and large mining capital in Mexico. Latin American Perspectives, 32(4), 65-86. https://doi.org/10.1177/0094582X05278139

Dittrich, M., \& Bringezu, S. (2010). The physical dimension of international trade. Part 1: direct global flows between 1962 and 2005. Ecological Economics, 69(9), 1838-1847. https://doi.org/10.1016/j.ecolecon. 2010.04.023

EUROSTAT (Statistical Office of the European Union) (2001). Economy-wide material flow accounts and derived indicators. A methodological guide. EUROSTAT.

EUROSTAT (Statistical Office of the European Union) (2018). Economy-wide material flow accounts. Handbook. EUROSTAT.

Fischer-Kowalski, M. (1998). Society's metabolism. The intellectual history of material flow analysis. Part I, 1860-1970. Journal of Industrial Ecology, 2(1), 61-78.

Fischer-Kowalski, M., \& Hüttler, W. (1999). Society's metabolism. The intellectual history of material flow analysis, part II, 1970-1998. Journal of Industrial Ecology, 2(4), 107-136. https://doi.org/10.1111/j.15309290.2011.00366.x

Flores, G., Paré, L., \& Sarmiento, S. (1988). Las voces del campo: movimiento campesino y política agraria, 1976-1984. Siglo XXI.

Foster, J. B. (2000). Marx's ecology. Materialism and nature. Monthly Review Press.

Fry, M. (2011). From crops to concrete: Urbanization, deagriculturalization, and construction material mining in central Mexico. Annals of the American Association of Geographers, 101(6), 1285-1306. https://doi. org/10.1080/00045608.2011.584289

Fuente Carrasco, M. E., \& Barkin, D. (2011). Concesiones forestales, exclusión y sustentabilidad. Lecciones desde las comunidades de la Sierra Norte de Oaxaca. Desacatos, 37, 93-110.

Gilijum, S., Dittrich, M., Lieber, M., \& Lutter, S. (2014). Global patterns of material flows and their socioeconomic and environmental implications: A MFA study on all countries world-wide from 1980 to 2009. Resources, 3(1), 319-339. https://doi.org/10.3390/resources3010319

González Martinez, A. C. (2007). Material flow accounting of Mexico (1970-2003): sources and methods. Working Paper UHE/UAB-1.2007. Universitat Autonoma de Barcelona, Departament d'Economia i Historia Economica.

González de Molina, M., \& Toledo, V. (2011). Metabolismos, naturaleza e historia. Hacia una teoría de las transformaciones socioecológicas. Icaria.

González, H. (2019). What socioenvironmental impacts did 35 years of export agriculture have in Mexico? (1980-2014): A transnational agri-food field analysis. Journal of Agrarian Change, 20(1), 163-187. https://doi.org/10.1111/joac. 12343

González Martínez, A. C., \& Schandl, H. (2008). The biophysical perspective of a middle income economy: Material flows in Mexico. Ecological Economics, 68, 317-332. https://doi.org/10.1016/j.ecolecon.2008. 03.013

Guillén, A. (2016). Guardianes del territorio. Seguridad y justicia comunitaria en Cherán, Nurío y Ostula. Guadalajara. Grietas Editores.

Hewitt de Alcántara, C. (1980). La modernización de la agricultura mexicana 1940-1970. Siglo XXI.

Hornborg, A. (1998). Towards an ecological theory of unequal exchange: Articulating world system theory and ecological economics. Ecological Economics, 25, 127-136.

INEGI (Instituto Nacional de Estadística y Geografía) (2015). Sector energético. Estadísticas Históricas de México. INEGI.

Infante-Amate, J., Urrego Mesa, A. \& Tello Aragay, E. (2020). Las venas abiertas de América Latina en la era del antropoceno: un estudio biofísico del comercio exterior (1900-2016). Diálogos Revista Electrónica de Historia 21(2), 177-214. https://doi.org/10.15517/dre.v21i2.39736

Krausmann, F., Weisz, H., Eisenmenger, N., Schütz, H., Haas, W., \& Schaffartzik, A. (2015). Economy-wide Material Flow Accounting. Introduction and Guide. Version 1.0. Social Ecology Working Paper 151. Alpen-Adria-Universität Klagenfurt, Klagenfurt. 
Krausmann, F., Gringrich, S., Eisenmenger, N., Erb, K. H., Haberl, H., \& Fischer-Kowalski, M. (2009). Growth in global material use, GDP and population during the 20th Century. Ecological Economics, 68, 26962705. https://doi.org/10.1016/j.ecolecon.2009.05.007

Martínez Alier, J. (2011). El ecologismo de los pobres. Conflictos ambientales y lenguajes devaloración. $5^{\mathrm{a}}$ edición ampliada. Icaria

Martínez Alier, J. (2007). Social metabolism and environmental conflicts. Socialist Register, 47, $273-293$.

Martínez Alier, J., Kallis, G., Veuthey, S., Walter, M., \& Temper, L. (2010). Social metabolism, ecological distribution conflicts, and valuation languages. Ecological Economics, 70, 153-158. https://doi.org/10.1016/j. ecolecon.2010.09.024

Martínez Alier, J., \& Walter, M. (2016). Social metabolism and conflicts over extractivism. In F. de Castro, B. Hogenboom, \& M. Baud (Eds.), Environmental governance in Latin America (pp. 58-85). Palgrave Macmillan.

Muradian, R., Walter, M., \& Martínez Alier, J. (2012). Hegemonic transitions and global shifts in social metabolism: Implications for resource-rich countries. Introduction to the special section. Global Environmental Change, 22, 559-567. https://doi.org/10.1016/j.gloenvcha.2012.03.004

Navarro, M. L. (2015). Luchas por lo común. Antagonismo social contra el renovado cerca-miento y despojo capitalista de los bienes naturales en México. Bajo Tierra/Benemérita Universidad Autónoma de Puebla.

Paz, M. F. (2012). Deterioro y resistencias: conflictos socioambientales en México. In D. Tetreault, H. Ochoa, \& E. Hernández González (Eds.), Conflictos socioambientales y alternativas de la sociedad civil (pp. 27-47). ITESO.

Paz, M. F. (2014). Conflictos socioambientales en México: ¿Qué está en disputa? In M. F. Paz \& N. Risdell (Eds.), Conflictos, conflictividades y movilizaciones socioambientales en México: Problemas communes, lecturas diversas (pp. 13-58). UNAM-CRIM/MAPorrúa.

PEMEX (Petróleos Mexicanos) (2018). Anuario Estadístico. PEMEX.

Pérez Rincón, M., Vargas Morales, J., \& Crespo Marín, Z. (2018). Trends in social metabolism and environmental conflicts in four Andean countries from 1970 to 2013. Sustainability Science, 13, 635-648. https:// doi.org/10.1007/s11625-017-0510-9

Puyana Mutis, A. (2015). La economía petrolera en un Mercado politizado y global. México y Colombía. FLACSO Mexico.

Róbles Berlanga, H. M. (2017). Los efectos de lo presupuesto en el sector rural. Fundar.

Róbles Berlanga, H. M. (2012). (Trans)national agribusiness capital and land market dynamics in Mexico. Canadian Journal of Development Studies, 33(4), 529-551. https://doi.org/10.1080/02255189.2012. 747429

Russi, D., González Martínez, A. C., Silva Macher, J. C., Giljum, S., Martínez Alier, J., \& Vallejo, M. C. (2008). Material flows in Latin America. A comparative analysis of Chile, Ecuador, Mexico, and Peru, 1980-2000. Journal of Industrial Ecology, 12(5-6), 704-720. https://doi.org/10.1111/j.1530-9290.2008. 00074.x

Schlosberg, D. (2007). Defining Environmental Justice. Theories, Movements and Nature. Oxford University Press.

Sectretaría de Economía (2018). Estudio de la cadena productiva de la arena. Documento de análisis. Secretaría de Economía, Dirección General de Desarrollo Minero.

Silva, E., Akchurin, M. \& Bebbington, A. (2018). Policy effects of resistance against mega-projects in Latin America: An introduction. European Review of Latin American and Caribbean Studies 106, 25-46. https://doi.org/10.32992/erlacs.10397

Silva Ontiveros, L., Munro, P. G., \& Melo Zurita, M. L. (2018). Proyectos de Muerte: Energy justice conflicts on Mexico's unconventional gas frontier. Extractive Industries and Society, 5, 481-489. https://doi.org/10. 1016/j.exis.2018.06.010

Svampa, M. (2015). The 'commodities consensus' and valuation languages in Latin America. Alternautas, 2(1), 45-59.

Tavera Fenollosa, L. (2019). La tercera frontera minera en México: Ofensiva extractivista y conflictividad social. Política y Cultura, 52, 89-112.

Tello, C. (1996). La economía mexicana: Hacia el tercer milenio. Nexos, 223, 47-55.

Temper, L., del Bene, D., \& Martinez-Alier, J. (2015). Mapping the frontiers and front lines of global environmental justice: The EJAtlas. Journal of Political Ecology, 22(1), 255-278. https://doi.org/10.2458/v22i1. 21108

Tetreault, D. (2015). Los conflictos socioambientales en México. Aportaciones desde la antropología social. Sociedad y Ambiente, 1(7), 117-123.

Tetreault, D. (2020). The new extractivism in Mexico: Rent redistribution and resistance to mining and petroleum activities. World Development, 126, 1-10. https://doi.org/10.1016/j.worlddev.2019.104714 
Tetreault, D., McCulligh, C., \& Lucio, C. (Eds.). (2018). Social Environmental conflicts in Mexico. Resistance to dispossession and alternatives from below. Palgrave Macmillan.

Toledo, V. M., \& Barrera Bassols, N. (2017). Political agroecology in Mexico: A path toward sustainability. Sustainability, 9(268), 1-13. https://doi.org/10.3390/su9020268

Toledo, V. M., Garrido, D., \& Barrera-Bassols, N. (2015). The struggle for life Socio-environmental conflicts in Mexico. Latin American Perspectives, 42(5), 133-147. https://doi.org/10.1177/0094582X15588104

Urías, H. (1980). ¿Quién controla la minería mexicana? Comercio Exterior, 30(9), 949-965.

Vallejo, M. C. (2010). Biophysical structure of the Ecuadorian economy, foreign trade and policy implications. Ecological Economics, 70(2), 159-169. https://doi.org/10.1016/j.ecolecon.2010.03.006

Veltmeyer, H., \& Petras, J. (Eds.). (2014). The new extractivism. A post-neoliberal development model or imperialism of the twenty-first century? Zed Books.

Publisher's Note Springer Nature remains neutral with regard to jurisdictional claims in published maps and institutional affiliations. 